\title{
アプローチ空間の形状と吹き抜け空間の天井高の感覚量との関係 RELATIONSHIP BETWEEN BENDING PATTERN OF LEADING PASSAGES AND FEELING VALUE OF CEILING HEIGHT IN HIGH CEILING ROOM
}

\author{
杉山拓哉*1, 吉岡陽介*2 \\ Takuya SUGIYAMA and Yohsuke YOSHIOKA
}

\begin{abstract}
Two experiments were conducted for examine the relationship between the bending pattern of leading passage and the psychological ceiling height of a high ceiling room. 32 participants walked through the virtual environment including "high-ceiling-room" and "leadingpassage". Several experimental conditions are created by connecting different shaped " leading-passage" to "high-ceiling-room". The result indicates that the ceiling height in "high-ceiling-room" perceived higher when connecting the "leading-passage " of the upward slope than when connecting other shaped " leading-passage". It is suggested that the psychological ceiling height in "high-ceiling-room" can be controlled by passing through the approach space with a suitable shape.
\end{abstract}

Keywords : Immersive virtual environment, Openness feeling, High ceiling room, Leading Passage 没入型仮想環境, 開放感, 吹き抜け空間, アプローチ空間

\section{1. 研究背景}

\section{1 吹き抜け空間へのアプローチ}

吹き抜けは、規模や用途を問わず、様々な建築の内部空間の「顔」 として重用される。吹き抜けがもたらす心理的な開放感が、その建 築での空間体験をより印象的なものにすると期待されるからである。 吹き抜けのある空間に入ると、前後の天井高の変化から、頭上が 開放された感覚が生じる。この頭上方向の開放感の強さは、おもに 吹き抜け空間の天井の高さによって生起され、かつ規定される。確 かに、前後の天井高の変化が吹き抜けにおける開放感を決定づける 大きな要因であることは間違いないが、しかしこれに加えて、吹き 抜け空間に至るまでに通るアプローチの形状によっても、この開放 感の強さは制御できるのではないかと考える。

すなわち、同じ天井高のアプローチを通って、同じ天井高の吹き 抜けに出たとしても、アプローチが上り坂だった場合と下り坂だっ た場合では、吹き抜けでの開放感の強さは異なると考えられる。 水澤ら ${ }^{1)}$ は、縮尺 $1 / 4$ の模型を用いた実験によって、天井高の差 と頭上の開放感との関係性を明らかにした。積田ら ${ }^{2)}$ は、実際の吹 き抜け空間を対象にした実験を行い、空間の構成やテクスチャー・ 光などの内部環境と、空間認知の特性との関係を分析した。込山ら は寸法の可変が可能な実大空間での実験を行い、天井高の認知構造

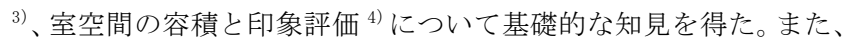
羽生 ${ }^{5)} 0 \mathrm{kabe}^{6)}$ 、Stefanucci $\mathrm{i}^{7)}$ らは視覚的な空間体験と距離認知との 関係を分析し、階段などの歩行経路の特性と認知距離との間に定性 的な相関があることを明らかにした。
このように、視覚情報が天井高などの空間の感覚量に与える影響 を調查した先行研究は数多くある。しかし、接続されたアプローチ の空間形状と吹き抜け空間の高さ方向の開放感（天井高の感覚量） との関係を明らかにしようとした研究はこれまでになかった。

\section{2 シークェンスと開放感}

建築は分節された「空間」の集合体である。分節されたそれらの 「空間」がシークエンスというネットワークを形成することで、奥 行きをもった建築がはじめて生まれる。シークエンスとは、「視点が 移動することで徐々に変化していく景色の連続」のことであり、建 築的な空間体験を説明する重要な概念である。

シークエンスに関する研究は幅広い論点から行われている。貝島 $ら^{8)}$ は、現代建築におけるシークエンスの類型化を行い、その構成 が、機能と合理性を超えた現代建築の意匠表現を成立させていると した。宮宇地ら 9)10) は、ショッピングモールでの分析を通じて、壁 や天井など身体移動と視線を遮る空間要素がシークエンスの評価に 影響を及ぼすことを明らかにした。空間は壁や床、天井などの要素 によって構築される。シークエンスとは、こうした空間を構成する 様々な要素を連続的に横断的に体験することであり、その連続と横 断を魅力的なものにする設計が現代建築には求められる。空間を構 成する諸要素がどのように連関しながら空間の感じ方に影響を与え ているのかを検証し、シークエンスを考慮した空間設計の知見とし て整備することが重要であると考える。

また、材野ら ${ }^{11)}$ は、シークエンス（景観）は「開放度」と「イン パクト度」によって記述できるとした。宮岸ら ${ }^{12)}$ も、寺院庭園のシ
11 (秼久米設計設計本部建築設計部 修士 (工学)

"2 千葉大学工学研究院 准教授·博士 (工学)
Architectural Design Dept., Architectural Div., KUME SEKKEI Co. Ltd., M.Eng.

Assoc. Prof., Graduate School of Engineering, Chiba University, Dr. Eng. 
ークエンスを分析し、「開閉度」の変化が視覚的行動に影響を与える ことを明らかにした。益岡ら ${ }^{13)}$ は各種の生理計測を用い、シークエ ンスに対する「開放感」が増加すると視覚行動量が増加し、開放感」 が減少すると歩行時間と前頭部の電位が減少することを明らかにし た。三ツ木ら ${ }^{14)}$ は、心理的分析により、経路探索時の心理変化をシ ークエンスとしてとらえ「不安度」を指標として定量化した。

特に材野、宮岸、益岡の研究では、「開放度（開閉度・開放感）」 がシークエンスを分析する際の重要な指標であるしている。そして、 一連のシークエンスの中に開放感のある部分が挿入されることによ って、シークエンス全体の評価が変化することを実験的に明らかに している。しかしながらその逆、ある空間に至るまでのシークエン シャルな体験がある空間での開放感に与える影響について、定量的 な検証を行った事例はこれまでになかった。そこで本研究では、吹 き抜け空間に至るまでのシークエンシャルな体験が吹き抜け空間で の高さ方向の開放感（天井高の感覚量）に与える影響について検証 を行うこととした。

\section{2. 目的}

本研究では、没入型仮想環境を用いた被験者実験を行い、その実 験結果を定量的に分析することによって、アプローチの空間形状と 吹き抜け空間の天井高の感覚量との関係を検証する。

吹き抜け空間にいたるアプローチの空間形状として「直進」「上る」 「下りる」「くぐる」「曲がる」の形状を設定し、それぞれの形状の アプローチを通り抜けることが、吹き抜け空間の天井に対する高さ 感に与える影響を検証する。またアプローチを歩行している際の被 験者の注視特性の分析を行うことで、アプローチの空間形状が視覚 的な情報探索にどのような影響を与えているのかを検証する。

これらの検証によって、吹き抜け空間の天井高を効果的に演出す るための知見を導出することを本研究の目的とする。

\section{3. 方法}

\section{1 没入型仮想環境}

本研究では没入型仮想環境技術を利用した被験者実験を行う。没 入型仮想環境技術を利用する利点としては、1）1/1 スケールでの空 間評価が可能であること、2）複数の空間条件を瞬間的に切り替えて 体験できること、3) 被験者によるインタラクティブな空間操作が可 能なこと、が挙げられる。本研究においてもこれらの利点を生かす ように仮想環境体験システムを構築した。

まず、仮想環境構築ソフトウェア：Vizard6. 0（WORLD VIZ 社製） を用いて、「吹き抜け空間」と「アプローチ空間」を含む仮想環境を 生成し、ヘッドマウントディスプレイ（実験 I ：HTC-VIVE/ HTC 社 (対角視野 110 度、リフレッシュレート 90Hz、片眼解像度 $10800 \mathrm{px}$ $\times 1200 p x ）$ 実験 II ：VIVE Pro Eye / HTC 社（対角視野 110 度、リフ レッシュレート $90 \mathrm{~Hz}$ 、片眼解像度 $1440 \mathrm{px} \times 1600 \mathrm{px})$ ) を介して、こ の仮想環境を被験者に等身大で体験させる。ヘッドマウントディス プレイに内蔵されたジャイロセンサおよび、実験室に配置した 2 基 のポジショントラッキングセンサ（Base Station/Valve 社）によっ て、被験者の頭部角度と位置情報を計測しリアルタイムで提示映像 に反映させた。これによって被験者はあたかも自分の体で仮想環境 内を歩き廻っているかのように感じることとなる(Fig. 1)。
また、実験条件間の移動は瞬間的な転送で行えるようにプログラ ミングした。被験者が仮想環境内の特定の時空間座標に到達すると、 次の実験条件の空間に瞬時に転送する。これによって被験者は、条 件間に不要なタイムラグを挟むことなく、いくつもの空間条件を連 続的に体験することができる。前の空間条件での感覚を鮮明に保持 したまま次の空間条件を評価することができる。

そして、被験者の手にはコントローラ(VIVE コントローラ/HTC 社) を把持させ、コントローラのボタン操作によって、仮想環境の天井 の高さを任意に変更できるようにプログラミングした。これによっ て、吹き抜け空間における天井高に対する感覚量を、被験者自身の 直感的操作により数值化することができる (Fig. 2)。

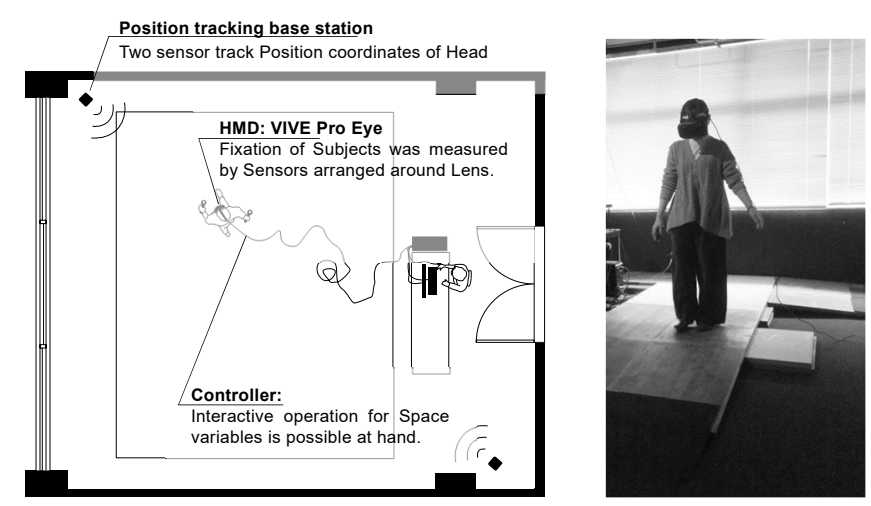

Fig.1 Experiment environment and arrangement

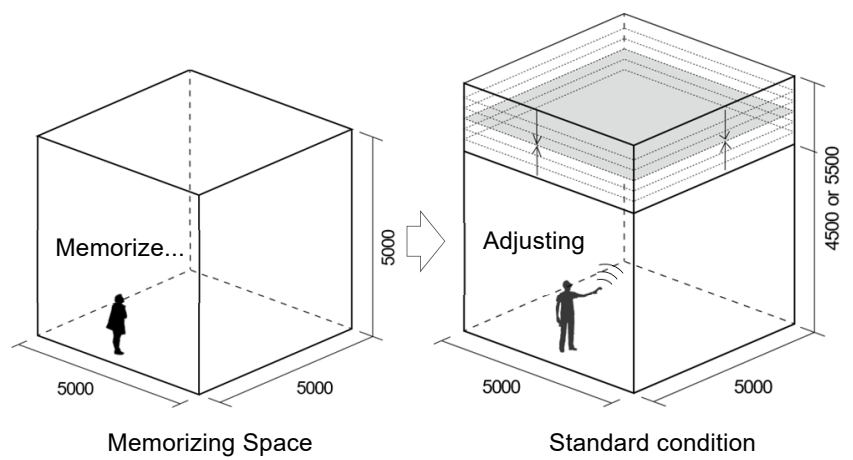

Fig.2 Measuring method for Experiment $1(\mathrm{~mm})$
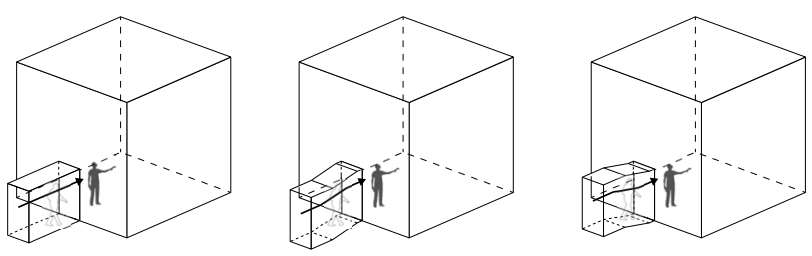

Go straight

Go up

Go down
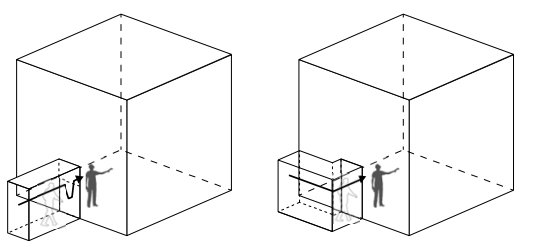

Turn left

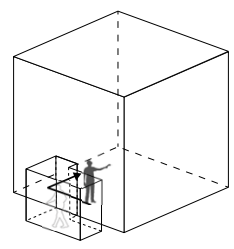

Turn right
Pass under

Fig.3 Schematic illustration of each experimental condition 


\section{2 実験環境}

実験は千葉大学の実験室 $(5900 \mathrm{~mm} \times 7000 \mathrm{~mm})$ で行った。この実験 室の二隅に、ポジショントラッキング用センサを設置し、およそ $4000 \mathrm{~mm} \times 5000 \mathrm{~mm}$ の範囲で被験者は仮想環境内で複数の空間条件を 体験しながら歩行できるように設定した Fig. 1)。被験者は 20 代の 健康な大学生 32 名（男 16 名、女 16 名）とした。

\section{4. 実験 I}

\section{1 実験条件}

仮想環境内に構築した「吹き抜け空間」の一辺に、6 種類の「アプ ローチ空間」を接続することで、6つの実験条件を作り出した (Fig. 3)。「吹き抜け空間」は、いずれも幅 $5000 \mathrm{~mm} \times$ 奥行 $5000 \mathrm{~mm}$ の 広さとした。吹き抜け空間の天井の高さは、先述の通り被験者の手 元のコントローラで任意に変更することができる。「アプローチ空間」 は、いずれも幅 $1000 \mathrm{~mm}$ 、高さ $2400 \mathrm{~mm}$ 廊下で、その形状によって、 「直進」「上る」「下る」「くぐる」「左曲り」「右曲り」の 6 つの身体 運動を被験者に促すこととなる。「アプローチ空間」の中央を歩いた 場合の「吹き抜け空間」までの移動距離はいずれの条件でもおよそ $4000 \mathrm{~mm}$ となる。

なお、「上る」「下る」条件では、奥行き $900 \mathrm{~mm}$ 高さ $100 \mathrm{~mm}$ のスロ ープを仮想環境内に配置するとともに、実空間の同位置にも同じ大 きさのスロープを設置することで、スロープ昇降にかかる負荷も体 験できるようにした。また、「くぐる」条件では、「吹き抜け空間」 と「アプローチ空間」との接合部に、おおよそ被験者の身長から頭 一つ分低く設定した垂れ壁を仮想環境内に設置し、頭部をぶつけな いようにくぐらせることとした。

また「アプローチ空間」を通過することの有無が、「吹き抜け空間」 の天井の高さの評価に与える影響を検証するため、「アプローチ空間 を接続しない「吹き抜け空間」のみの実験条件を追加した。この「吹 き抜け空間」のみの実験条件を「基準条件」と呼称することとする。 最後に、広さを幅 $5000 \mathrm{~mm} \times$ 奥行 $5000 \mathrm{~mm} \times$ 天井高 $5000 \mathrm{~mm}$ に固定し た直方体の空間を用意し、「記憶空間」とした（Fig. 2)。

\section{2 天井高の調整}

本研究では、天井高に対する直感的な感覚量を数值化するために、 天井の高さ方向の位置を、被験者自身の操作により上下に調整させ る方法をとる。各実験条件における「吹き抜け空間」の天井は、被 験者が手元に持っているコントローラのホイールで、その高さを $50 \mathrm{~mm}$ 間隔で上下に調整できるようにプログラミングした。

被験者はまず「記憶空間」を体験し、その天井高 $5000 \mathrm{~mm}$ を記憶す る。その直後、7つの実験条件のうちいずれかに瞬間移動し、「アプ ローチ空間」をたどって、「吹き抜け空間」まで歩行する。「吹き抜 け空間」に到着した被験者は、記憶の中にある「基準空間」の天井 高と一致するよう、各実験条件における天井高を調整する。

このとき仮に、被験者が天井高を、「記憶空間」の天井高 $5000 \mathrm{~mm}$ より低く $4800 \mathrm{~mm}$ 程度に調整したとする。この場合は、被験者は調整 後の $4800 \mathrm{~mm}$ の天井高を $5000 \mathrm{~mm}$ 相当だと評価しているわけであるか ら、その分だけ実際の寸法より天井を高く感じていることになる。 すなわち、調整後に見えている天井に対して被験者は、 $5000 \mathrm{~mm}$ と $4800 \mathrm{~mm}$ の差分である $200 \mathrm{~mm}$ 分だけ、その高さ方向の位置を高く感じ ていると解釈することができる。
なお、「吹き抜け空間」の天井高はあらかじめ、目標より $500 \mathrm{~mm}$ 低 い $4500 \mathrm{~mm}$ と、目標より $500 \mathrm{~mm}$ 高い $5500 \mathrm{~mm}$ のいずれかに設定されて いる(Fig. 2)。被験者には「吹き抜け空間」の天井高を「上下方向ど ちらかに変えてある」ことのみを伝えている。なお、順序効果を相 殺するため、各実験条件の提示順は被験者ごとにランダムとした。

\section{3 実験手順}

まず、被験者の頭部にヘッドマウントディスプレイを装着させ、 天井高を調整するためのコントローラを持たせる。その後、実験条 件ごとに(1)〜 (6)の手順で試行を繰り返した。

（1)試行開始とともに「記憶空間」に被験者を転送する。

(2) 10 秒間で「記憶空間」の天井高 $5000 \mathrm{~mm}$ を記憶させる。

(3) 被験者を、各実験条件のスタート地点に転送する。

(4)転送後すみやかに「アプローチ空間」を通過し、「吹き抜け 空間」まで歩行してもらう。「アプローチ空間」が接続され ていない基準条件では、そのまま手順(5)進む。

（5）記憶した「記憶空間」の天井高と同じになるように、コント ローラで「吹き抜け空間」の天井高を調整してもらう。

(6) 天井高の調整が完了したら被験者に口頭で合図をしてもら い、次の実験条件の手順(1)進む。

「吹き抜け空間」の調整前の天井高 2 パターンに 7 つ実験条件 を掛け合わせた計 14 回の試行を被験者ごとに実施した。なお、へッ ドマウントディスプレイを装着させる際には、被験者の個人特定に あわせて左右のレンズ間の距離、レンズと眼球の間の距離を調整し た。被験者にはヘッドマウントディスプレイを装着した状態での歩 行に慣れさせるため、試行前に 5 分程度、仮想環境内を歩き迴らせ た。試行と試行の間では、随時ヒアリングを行い、酔い等の違和感 があった場合は即座に実験を中断するルールで運用したが、本実験 では該当者はいなかった。

\section{4 実験結果}

「記憶空間」の天井高 $5000 \mathrm{~mm}$ と、各実験条件で被験者が調整した あとの天井高を比較することで、接続された「アプローチ空間」の 形状と、「吹き抜け空間」における天井高の感じ方との関係を分析す る。各実験条件における調整後の天井高について、被験者平均を求 めたところ (Fig. 4)、基準条件での調整後の天井高は $4983 \mathrm{~mm}$ であっ た。調整前の天井高が $4500 \mathrm{~mm}$ であった場合と $5500 \mathrm{~mm}$ では、調整後 の天井高に比較的大きな差があるものの（Fig. 5)、平均值で比較す るかぎりでは基準条件での調整後の天井高は目標值の $5000 \mathrm{~mm}$ に最 も近い值であり、実験結果の分析手法としては調整前の天井高によ る差を平均したデータを比較することに一定の妥当性が与えられる。 まず、各実験条件における調整後の天井高について、「アプローチ 空間」の接続の有無と「アプローチ空間」の形状を要因とした二元 配置分散分析を行った。その結果、二つの要因に対する帰無仮説が 棄却された。このことから「アプローチ空間」の接続の有無によっ て、吹き抜け空間」での天井高の感じ方が変化することが分かった。 また、「アプローチ空間」の形状によって、「吹き抜け空間」での天 井高の感じ方が変化していることも分かった。

つづいて、実験条件「直進」「上る」「下る」「くぐる」「左折」「右 折」における調整後の天井高に対して、Bonferroni 法による多重比 較検定 $(5 \%$ 水準 $)$ を実施した。しかしながら、ここでは実験条件間 
での有意差は見られなかった。そこで、データ推移の様相から、「ア プローチ空間」が斜路であることの効果に着目し、「直進」「上る」 「下る」における調整後の天井高に対して、一元配置分散分析と多 重比較検定を行った。その結果、通り実験条件「直進」と「上る」 との間に有意差が認められた $(\mathrm{p}=0.0149)$ 。

\section{5. 考察}

実験結果より、直進のみの「アプローチ空間」を接続する条件よ り、上り方向に傾斜のついた「アプローチ空間」を接続する条件の 方が、直後の「吹き抜け空間」での天井高が高めに調整されること が確認された。すなわち、「アプローチ空間」の先の「吹き抜け空間」 の天井高が同じであっても、「アプローチ空間」に斜路がある場合に は、斜路がない場合より天井高を低く感じている。

上り方向に傾斜のついた「アプローチ空間」の形状が被験者の視 線を前方上方に移し、奥の「吹き抜け空間」の天井方向の見通しが 良くなることで、「アプローチ空間」から「吹き抜け空間」へ抜ける 際の開放感が薄れたと推察される。

ただし、下り方向に傾斜のついた「アプローチ空間」を接続した、 実験条件「下る」のデータをみると、平均值の推移としては実験条 件「直進」と「上る」の中間あたりに位置していることがわかる

(Fig. 5)。実験条件「下る」では斜路を下っているため、上記の仮 説に従えば、実験条件「直進」のデータよりも下側に位置していな ければならないはずである。

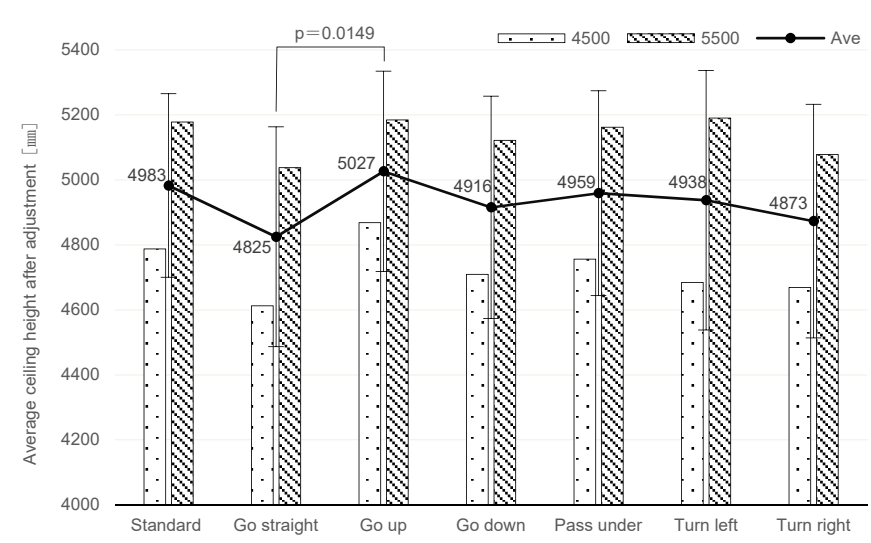

Fig.4 Comparison of subject-adjusted ceiling height under each experimental condition (Error bar means SE)

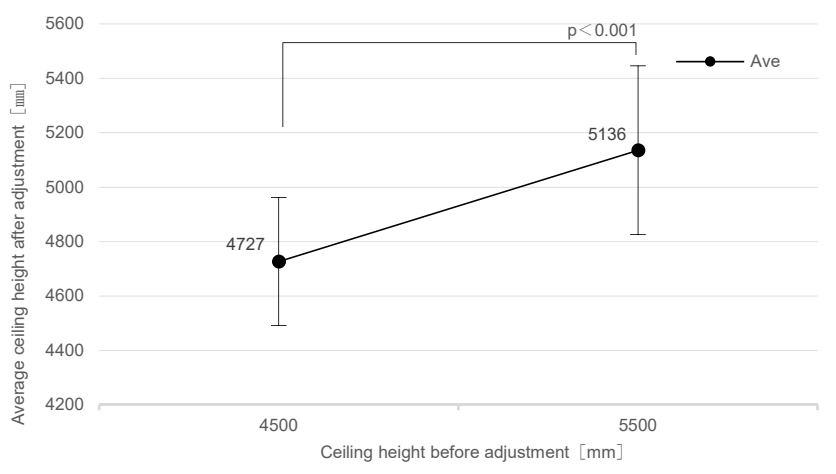

Fig. 5 Comparison of the adjusted ceiling height under the conditions of $4500 \mathrm{~mm}$ and $5500 \mathrm{~mm}$ (Error bar means SE)
今回の実験結果からは、実験条件「下る」と、基準条件と実験条 件「直進」、上る」との間には、統計的に有意な差は見られていな いが、先の推察に反するデータ推移である。また、+500 $\mathrm{mm}$ の井 高から調整する場合と、 $-500 \mathrm{~mm}$ の井高から調整する場合とで、 最終的な調整後の天井高に差異が生じていることも明らかである。

実験 II ではこうした問題が生じない実験方法を考案する。また「吹 き抜け空間」の天井方向の見通しの良さが天井高の調整に影響を与 えている、とする先述の推察を確認するため、アプローチ空間での 被験者の注視特性の分析も行う。

\section{6. 実験 II \\ 6.1 実験条件}

実験 I の考察を受けて、「直進」「上る」「下る」の実験条件に焦点 を絞り、注視特性分析を伴う追加実験を行った。実験 II で使用する ヘッドマウントディスプレイ（VIVE Pro Eye / HTC 社）では、接眼 レンズの奥に設置されたカメラとその周囲に設置された LED 光源に より、被験者の注視点の位置を高精度（120Hz、精度 0.5-1.1 度）で 抽出することができる。

実験 I と同じく、仮想環境内に構築した「吹き抜け空間」の一辺 に、 3 種類の「アプローチ空間」を接続することで、「直進」、上る」、

「下る」の 3 つの実験条件を作り出した (Fig. 3 上段)。

「吹き抜け空間」は、いずれも幅 $5000 \mathrm{~mm} \times$ 奥行 $5000 \mathrm{~mm}$ 広さとし、 天井高はこの実験では $5000 \mathrm{~mm}$ に固定した。「アプローチ空間」は、 実験 I と同じく幅 $1000 \mathrm{~mm}$ 、高さ $2400 \mathrm{~mm}$ の廊下で、中央を歩く場合 の移動距離はおよそ $4000 \mathrm{~mm}$ となる。だし、「上る」、「下る」の実 験条件で設置したスロープについては、実験 I の 2 倍の寸法（奥行 $1800 \mathrm{~mm}$ 、高さ $200 \mathrm{~mm}$ ) を適用して実験を行う。昇降する距離と高さ が大きくなることによって、スロープによる効果がより顕在化しや すくなると考える。実験 I 同様、実空間にも同じ大きさのスロープ を設置し、スロープ昇降にかかる負荷を体験できるようにした。

また、「吹き抜け空間」のみの「基準条件」を設け「アプローチ空 間」を通過することの有無が、「吹き抜け空間」の天井の高さの評価 に与える影響を検証する。最後に、広さを幅 $5000 \mathrm{~mm} \times$ 奥行 $5000 \mathrm{~mm}$ に固定し、天井の高さを被験者の手元のコントローラで任意に変更 することができる空間を用意し、「再現空間」とした（Fig. 6)。

\section{2 天井高の調整}

実験 I では各実験条件の「吹き抜け空間」の天井高を $5000 \mathrm{~mm}$ 相当 に調整させて、その調整の加減によって被験者の感じた天井の高さ を定量化した。調整前の天井高は $4500 \mathrm{~mm} 、 5500 \mathrm{~mm}$ の 2 種類であっ たが、どちらの天井高から調整をはじめるかで、最終的な調整後の 天井高に有意な差異が生じていた。目標值プラスマイナス $500 \mathrm{~mm}$ と いう值の設定も、実験的検証のための暫定值とはいえ染意的であっ た。また、各実験条件の「吹き抜け空間」の天井高を調整する手法 であっため、厳密には直前に体験した「記憶空間」の天井高を再現 し計測する手続きとなっていた。

そこで実験 II では、プロセスを逆にし、被験者が各実験条件で感 じた「吹き抜け空間」の天井の高さを、「再現空間」において再現さ せる方法をとることとした。まず被験者に、天井高が $5000 \mathrm{~mm}$ である ことを伏せた状態で、各実験条件の「吹き抜け空間」を体験させる。 つまり実際には「吹き抜け空間」の天井高は $5000 \mathrm{~mm}$ で一定である 
が、被験者には「5000 mmより高いかもしれないし、低いかもしれな いし、ぴったり $5000 \mathrm{~mm}$ かしれない」と告げておく。

各実験条件の「吹き抜け空間」の天井高を記憶させたあと、いっ たん目を閉じさせ、その間に「再現空間」に被験者を転送する。転 送された「再現空間」において、記憶の中にある各実験条件の「吹 き抜け空間」の天井高と一致するよう、天井高を調整させる。被験 者が「再現空間」で再現した天井高と、目標值である $5000 \mathrm{~mm}$ との間 にどのくらい差異が生じるかを分析することで、「アプローチ空間」 の効果を検証する。

この実験 II においては、各実験条件の天井高と「再現空間」の天 井高は、いずれも $5000 \mathrm{~mm}$ で統一している。であるにもかかわらず、 「再現空間」での調整後の天井高と各実験条件の「吹き抜け空間」 の天井高との間に差異が生じていたとすると、それは各実験条件の 「アプローチ空間」を通過することによって、「吹き抜け空間」に出 た際に天井高を高くもしくは低く感覚していたものと推察できる。

また実験 II ではアプローチ空間での被験者の注視特性の分析を行 う。この実験 II の方法であれば、「吹き抜け空間」の天井高は 5000 $\mathrm{mm}$ に固定されているため、目標值である $5000 \mathrm{~mm}$ の天井高を持つ「吹 き抜け空間」へのアプローチに際しての注視特性を、正確にデータ として取得することができる。実験 I の方法では、4500 mmあるいは $5500 \mathrm{~mm}$ への天井高を持つ「吹き抜け空間」に対する注視特性の分析 しかできなかった。

\section{3 実験手順}

ヘッドマウントディスプレイを装着した被験者にコントローラを 持たせ、注視特性分析のためのキャリブレーション（9 点）をおこ なった。その後、実験条件ごとに(1)〜6の手順で試行を繰り返した。

(1) 各実験条件のスタート地点に被験者を転送する。

(2) 転送後すみやかに「アプローチ空間」を通過し、「吹き抜 け空間」まで歩行してもらう。「アプローチ空間」が接続 されていない基準条件では、そのまま手順(3に進む。

(3) 10 秒間で「吹き抜け空間」の天井高 $5000 \mathrm{~mm}$ を記憶させる。

(4) 閉眼して 10 秒を数えさせ、その間に「再現空間」に転送。

(5)記憶した「吹き抜け空間」の天井高と同じになるように、 コントローラで「再現空間」の天井高を調整してもらう。

(6) 天井高の調整が完了したら被験者に口頭で合図をしても らい、次の実験条件の手順11に進む。

4 つの実験条件を被験者ごとランダムに実施した。没入型仮想環 境の利用にあたっては実験 I と同様のスキームとルールで運用した。

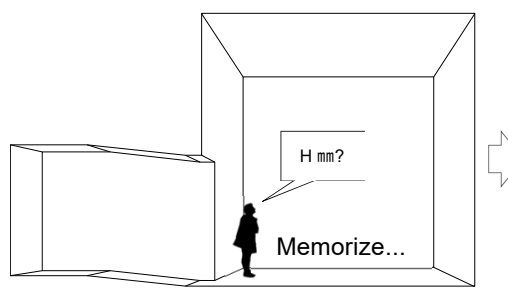

"Go up" condition

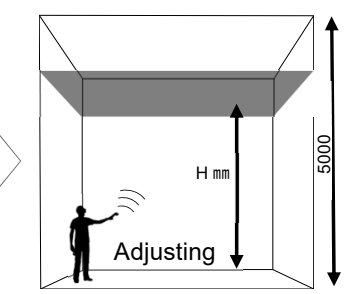

Adjusting Space
Fig.6 Measuring method for Experiment $2(\mathrm{~mm})$

\section{4 実験結果}

\subsection{1 調整後の天井高}

「アプローチ空間」が接続されていない基準条件での調整後の天 井高を 1 として、実験条件「直進」、上る」、「下る」での調整後の 天井高の比率を求めた（Fig. 7)。実験条件「直進」と「下る」にお いて比率が 1 よりも大きくなっており、逆に実験条件「上る」にお いて比率が 1 よりも小さくなっている。実験 I の結果に比べて、デ 一タの推移が反転しているように見えるが、これは実験のプロセス が逆転しているためである。1 より大きい值であれば、その条件に おいて基準条件より天井高を高く感じていると解釈できる。実験 II では各実験条件の天井高と「再現空間」の天井高がいずれも $5000 \mathrm{~mm}$ であったため、「再現空間」の天井高が初期状態からまったく動かさ れないことも予想されたが、実験条件ごとに数值に変動があり、ア プローチ空間の接続による天井高の感覚の変化が計測できているこ とがわかる。

そこで、実験条件「直進」「上る」「下る」それぞれの調整後の天 井高について、「アプローチ空間」の形状を要因とした一元配置分散 分析を行った。その結果、主要因に対寸る帰無仮説が棄却された。 このことから「アプローチ空間」の形状によって、「吹き抜け空間」 での天井高の感じ方が変化していることが分かった。つづいて Bonferroni 法による多重比較検定を実施したところ、実験条件「上 る」と「下る」の間に有意差が認められた $(\mathrm{p}=0.0445)$ 。実験条件 「下る」では、実験条件「上る」よりも天井高を高く感覚している ことが確認された（Fig. 7)。

\section{4 .2 注視特性（視線仰角）}

実験条件「上り」と実験条件「下り」における被験者の注視特性 を比較する。「アプローチ空間」を歩行するときの注視特性について、 本研究では上下方向の視線移動に絞って分析を行う。この分析によ り、被験者が「アプローチ空間」を歩行中どのタイミングで視線を 上げて、「吹き抜け空間」の視覚情報を取得しょうとしているのかを 検証する。

ヘッドマウントディスプレイから出力される注視特性の時系列デ ータから、被験者が「アプローチ空間」を歩行している間の視線仰 角 $\theta$ を、水平方向を 0 、上方向を正として収集した（Fig. 8)。つづい て「アプローチ空間」の歩行開始地点を 0 として、200 mm間隔で視 線仰角の平均值を算出し、さらにそれぞれの区間での被験者平均を 算出した (Fig. 9)。

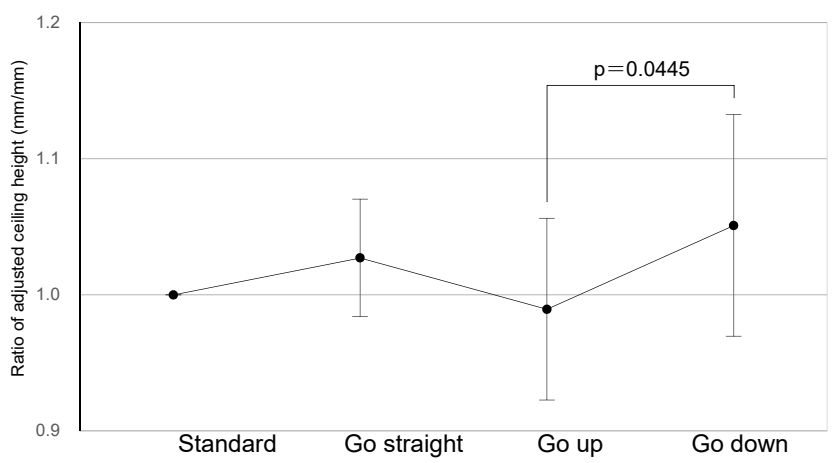

Fig.7 Ratio of adjusted ceiling height under each experimental condition to standard condition (Error bar means SE) 
データの推移をみると実験条件「上り」と「下り」ともに、「吹き 抜け空間」に近づくにつれて次第に視線仰角が正方向に増大寸る傾 向がみられた。また、区間 1000-1200 mm と区間 1200-1400 mmにおい て実験条件「上り」のデータが特異に正方向に上昇している。

そこで $200 \mathrm{~mm}$ 毎の区間での視線仰角の平均值に対して「アプロー チ空間」の形状を要因とした Bonferroni 法による多重比較検定を 実施した。その結果、区間 1000-1200 mm、区間 1200-1400 mm と区間 1800-2000 mmで実験条件「上る」と「下る」の間に有意差が認められ た $(\mathrm{p}=0.0004 、 \mathrm{p}=0.0027 、 \mathrm{p}=0.0062)$ 。実験条件「下る」と比 較すると、実験条件「上る」では、区間 1000-1200 mm、区間 1200$1400 \mathrm{~mm}$ においてより上方へ視点を移動し、区間 1800-2000 mmにおい てより下方へ視点を移動していることが分かった。

\section{7. 考察}

まず調整後の天井高の推移について考察する。基準条件での感覚 量を基準にすると、実験条件「直進」と「下る」では天井高をより 高く感覚し、逆に実験条件「上る」では天井高をより低く感覚する、 という傾向がある（Fig. 7)。この傾向は実験 I の結果と共通してい る（Fig. 4）。実験方法の違いにもかかわらず共通の傾向が確認でき たことで、この傾向が頑健であることを示すことができた。

ただし、統計的な有意差は実験 I とは異なる部分で検出されてい る。実験 I では、実験条件「直進」と「上る」の間に有意差が見ら れたが、実験 II では、実験条件「下る」と「上る」の間に有意差が 見られた。実験プロセスを逆転させたことと、スロープのサイズの 変更 (奥行 $900 \mathrm{~mm}$ 、高さ $100 \mathrm{~mm} \rightarrow$ 奥行 $1800 \mathrm{~mm}$ 、高さ $200 \mathrm{~mm}$ ) のどち らか、あるいはその両方が影響を与えていると考えられる。

また各実験条件の平均值の推移を比較すると、実験 I では、実験 条件「直進」の平均值が実験条件「下る」と「上る」よりも下方に 位置している（Fig. 4)。それに対して、実験 II では、実験条件「下 る」と「上る」の中間あたりに位置している（Fig. 7)。実験 II の結 果の方が、「吹き抜け空間」の天井方向の見通しの良さが天井高の調 整に影響を与えている、とする仮説よく裏付けているといえる。

つづいて「アプローチ空間」での視線仰角の推移について考察す る。Fig. 9 に見られるデータ推移では、実験条件「上る」、「下る」と もに右肩上がりに視線仰角が推移していた。これは、「アプローチ空 間」を前に進むにつれて「吹き抜け空間」を視認できる領域が広が り、その中でも特に前方上方、すなわち「吹き抜け空間」の天井方 向を見る傾向にあるためだと推察される。平均值が正の值に転じる のは区間 2000-2199を過ぎたあたりからではあるが、両条件とも地 点 1400 を超えたあたりから前方上方に視線を移寸割合が増加して おり、そのことが平均值に次第に反映された結果、右肩上がりの推 移が形成されている。

また、区間 1000-1199 mm と区間 1200-1399 mmにおいて実験条件「上 る」の視線仰角は大きく上昇しており、実験条件「下る」における 視線仰角との比較では有意な差が確認されていた。本実験の被験者 の平均身長は $1688 \mathrm{~mm}$ である。このことを考慮すると、区間 $1000-$ $1200 \mathrm{~mm}$ とは、実験条件「上る」においては被験者が「吹き抜け空間」 の天井を注視することができ、実験条件「下る」においては「吹き 抜け空間」の天井を注視することがぎりぎりできない、という特別 な区間であることがわかる（Fig. 10）。

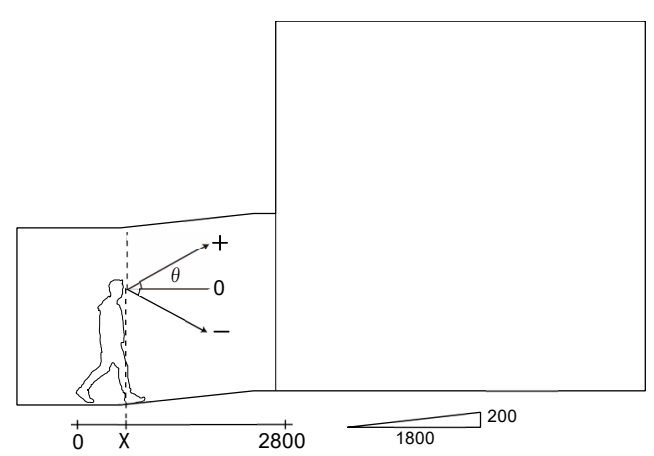

Fig. 8 Visual angle $\theta$ at point of $x$ in "approach space" $(\mathrm{mm})$

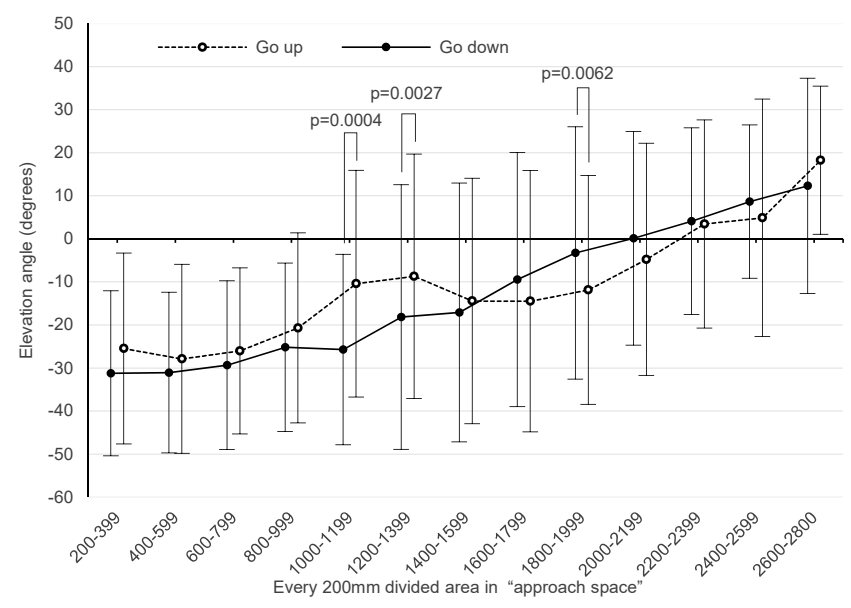

Fig.9 Average visual angle at every $200 \mathrm{~mm}$ divided area under "Go up" and "Go down" conditions (Error bar means SE)

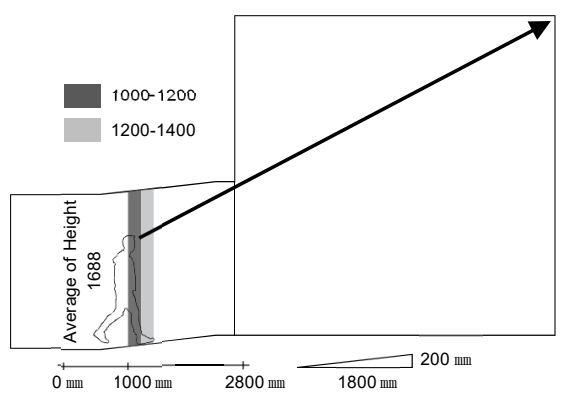

Experimental condition "Go up"

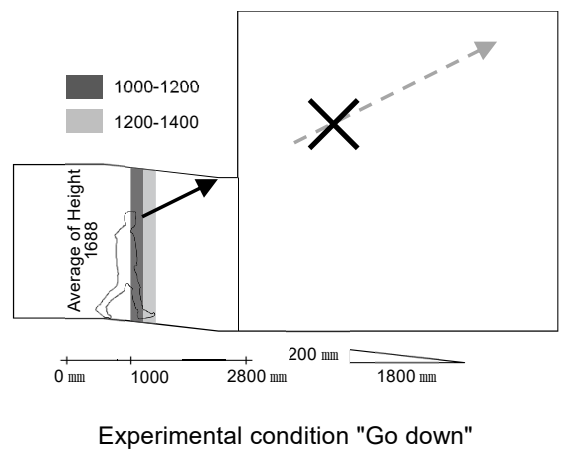

Fig.10 Relationship between visual angle and section in "approach space" of experimental condition "Go up" and "Go down" 
実験条件「上る」では 10 人中 4 人の被験者が地点 $1200 \mathrm{~mm}$ 未満の 位置で、縦方向上方に視線を移し、「吹き抜け空間」の天井付近（天 井と壁の境界）を注視していた。それ対して実験条件「下る」では、 同程度まで前方上方に視線を移したのは 10 人中 1 人であった。

また統計的に有意な差は無いものの地点 $1600 \mathrm{~mm}$ までは、実験条 件「下る」のほうが実験条件「上る」より常に被験者の視線仰角が 下がる傾向にあった Fig. 9)。実験条件「下る」における「アプロー チ空間」は、下り方向に傾斜をつけて延びているため、安全確認の ために床面を注視するにはより下方へ視線を移さなければならない。 このことが地点 $1600 \mathrm{~mm}$ までの区間における視線仰角の低下を招い たと考えられる。地点 $1600 \mathrm{~mm}$ を過ぎたあたりで床面への注視の必 要がなくなり、地点 $1800 \mathrm{~mm}$ で統計的有意差が確認されるほどに前 方上方に視線を移寸割合が増加したのではないだろうか。

以上のように、実験条件「上る」と「下る」との間には、注視特 性に特徴的な差があることが示された。このことが、二つの条件間 での天井高の感覚量の違いに影響を与えた可能性が考えられる。ス ロープの途中で「吹き抜け空間」の天井を視認することで、心的表 象としての「天井」が生成される。そこからさらにスロープを上る ことでその「天井」に接近する感覚が生じる。この「天井」に接近 する感覚が、「天井」に接近したはずだという感覚に変わり、「吹き 抜け空間」での天井高の感覚量に影響を与えたのではないだろうか。

本研究では、二つの事象の因果関係にまで踏み込むことはできて いないが、実験条件に応じた感覚量の変化(調整後の天井高の変化) と、実験条件の与件に依存しているとみられる行動的な特徵（「吹き 抜け空間」天井付近への注視)、この両方を一つの実験の中で確認で きたことは重要である。二つの事象の因果関係を明らかにするため には、何らかの方法で視線仰角を下方に固定した実験を行い、調整 後の天井高の変化が生じなくなることを確認する必要がある。

\section{8. まとめ}

本研究では没入型仮想環境技術を用いた $2 つ の$ 被験者実験を行い、 「アプローチ空間」の形状と「吹き抜け空間」の天井高の感覚量と の関係を検証した。二つの実験の結果を以下にまとめる。

実験 I：

被験者に、「直進」「上る」「下る」「くぐる」「左折」「右折」の 6 種類の形状の「アプローチ空間」を通って「吹き抜け空間」まで歩 いてもらい、天井高を調整させたところ、以下の結果を得た。

「アプローチ空間」の接続の有無によって、直後の「吹き抜け空 間」での天井高の感覚量が変化する。

・「アプローチ空間」の形状によって、直後の「吹き抜け空間」で の天井高の感覚量は変化する。

・平坦な「アプローチ空間」を通るより、上り方向に傾斜のついた 「アプローチ空間」を通る方が、直後の「吹き抜け空間」での天 井高が低く感覚される。

\section{実験 II ：}

被験者に、「直進」「上る」「下る」の 3 種類の形状の「アプローチ 空間」を通って「吹き抜け空間」まで歩いてもらい、そこでの天井 高に対する感覚量を計測したところ、以下の結果を得た。
実験 I と同じく、「アプローチ空間」の形状によって「吹き抜け 空間」での天井高の感覚量が変化していることが分かった。

下り方向に傾斜のついた「アプローチ空間」を通るより、上り方 向に傾斜のついた「アプローチ空間」を通る方が、直後の「吹き 抜け空間」での天井高が低く感覚される。

・上り方向に傾斜のついた「アプローチ空間」を歩くときには、 「アプローチ空間」の出口越しに「吹き抜け空間」の天井が見え 始める位置において、下り方向に傾斜のついた「アプローチ空 間」を歩くときよりも、上方を注視する。

・ 下り方向に傾斜のついた「アプローチ空間」を歩くときには、 「アプローチ空間」の出口付近において、上り方向に傾斜のつ いた「アプローチ空間」を歩くときよりも、上方を注視する。

以上より、相応な形状の「アプローチ空間」を通過させることに よって、直後の「吹き抜け空間」での天井高の感覚量を操作できる 可能性が示された。また両実験に共通して、「アプローチ空間」の ない場合と比較寸ると、平坦な「アプローチ空間」や下り方向に傾 斜のついた「アプローチ空間」を通ると天井高をより高く感覚し、 上り方向に傾斜のついた「アプローチ空間」を通ると天井高をより 低く感覚する、という傾向も確認された。

なお本研究で得られた知見にはいくつかの適用限界がある。まず ヘッドマウントディスプレイを介した没入型仮想環境における実験 的検証であるため、模型や映像などを利用した実験的検証の知見と 同様、現実空間での追加の検証が必要である。また設定寸法につい ても、特に吹き抜け空間の天井高を $5 \mathrm{~m}$ に設定しているが、ほかの 高さの吹き抜け空間でも同様の結果になるのかを検証する必要があ る。「アプローチ空間」の廊下幅や天井の形状も一考の余地がある。 特に本研究の「アプローチ空間」の天井は、床面の傾斜に同調して 上下していた。床と天井との間の距離が「アプローチ空間」各部で 変化することによる実験結果への影響を排除するためである。しか し実際の建築の計画でこのような傾斜した天井の廊下を設計するこ とは稀である。現実空間の設計に本研究の知見を適用するためには こうした細部の検証が必要になる。一方で本研究では切り分けて検 証しなかった別の論点もある。筋肉への刺激の有無である。傾斜の 付いた「アプローチ空間」を上ったり下ったりする場合には、被験 者の両足にかかる負荷が、平坦な「アプローチ空間」を歩く場合と は明らかに異なる。この身体的負荷が実験結果に影響を与えていた 可能性がある。以上の事項を今後の課題としたい。

\section{参考文献}

1) Mizusawa S., Yajima, N., Naoi,H.:An experimental study on change of felt overhead-space by person moving to room of higher ceiling, Summaries of Technical Papers of Annual Meeting, Architectural Institute of Japan, E-1, pp. 825-826, 2004.7

水澤秀輔, 矢島規雄, 直井英雄：天井高の異なる二空間を通り抜ける 時の頭上開放感の変化に関寸る実験, 日本建築学会大会学術講演梗概 集，E-1，pp. 825-826，2004.7

2) Tsumita, H., Tamao, Y., Hua, Xu.: Study on Spatial Cognition of Width, Depth and Height in Spaces in Well-Hole Style, Journal of Architecture and Planning (Transactions of AIJ), Vol.75, No.648, 315-320, 2010.2

積田洋，玉尾祐輝，徐華：吹抜け空間における幅・奥行・高さの認知 
特性の研究, 日本建築学会計画系論文集, Vol. 75 , No. 648 , pp. 315320, 2010. 2

3) Komiyama, A., Hatsumi, M.: Cognitive Structure of Ceiling Height of Interior Space, Journal of Architecture, Planning and Environmental Engineering (Transactions of AIJ), No.490, pp.111$118,1996.12$

込山敦司, 初見学: 建築内部空間における天井高の認知構造, 日本建 築学会計画系論文集, No. 490, pp. 111-118, 1996. 12

4) Komiyama, A., Hashimoto, K., Hatsumi, M., Takahashi, T.: Experimental Study on Evaluation of Volume and Spaciousness of Interior-Space,Journalof Architecture, Planning and Environmental Engineering (Transactions of AIJ), No.496, pp.119-124, 1997.6 込山敦司, 橋本都子, 初見学, 高橋鷹志：室空間の容積と印象評価に 関する実験的研究, 日本建築学会計画系論文集, No. 496, pp. 119-124, 1997. 6

5) Hanyu, K., Itsukushima, Y.: Empirical Studies on Cognitive Distance of Stairways, IATSS Review, Vol.25, No.4, pp.243-253, 2000.8

羽生和紀, 厳島行雄: 階段の認知距離の実証実験, IATSS Review, Vol. 25, No. 4, pp. 243-253, 2000.8

6) Okabe, A., Aoki, K., Hamamoto, W.: Distance and Direction Judgment in a Large-Scale Natural Environment, Effects of a Slope and Winding Trail, Environment and Behavior, Vol.18, No.6, pp.755772,1986

7) Stefanucci,J.K., Proffitt,D.R., Banton,T., Epstein,W.: Distances appear different on hills, Attention, Perception, \& Psychophysics, Vol.81, No.6, pp.1052-1060, 2005

8) Kaijima, M., Sakamoto, I., Tsukamoto, Y.:The Connection of Rooms in Circulation Path -A study on spatial composition in circulation path in Japanese contemporary architecture, Journal of Architecture, Planning and Environmental Engineering (Transactions of AIJ), Vol.62, No.498, pp. 131-138, 1997.8 貝島桃代，坂本一成，塚本由晴，動線による室の連結 ：現代日本の 建築作品における動線の空間構成に関する研究, 日本建築学会計画系 論文集, Vol.62, No. 498, pp. 131-138, 1997.8

9) Miyauji, K.: A Study on the Sequence of Visual Environment with Human Movement Part 1, Case study on shopping malls, Journal of Architecture, Planning and Environmental Engineering (Transactions of AIJ), No.440, pp. 99-109, 1992.10 宮宇地一彦：人間移動に伴う視覚的シークエンスの研究（その1), シ ヨッピングモールを事例として, 日本建築学会計画系論文報告集, No. 440, pp. 99-109, 1992.10

10) Miyauji, K.: A Study on the Sequence of Visual Environment with Human Movement Part 2, An analysis of sequential characteristics and verification of the sequential notation, Journal of Architecture, Planning and Environmental Engineering (Transactions of AIJ), Vol.59, No.455, pp. 97-108, 1994.1 宮宇地一彦：人間移動に伴う視覚的シークエンスの研究 (その 2 ), シ 一クエンスの特徵分析と表記法の検証, 日本建築学会計画系論文集, Vol. 59, No. 455, pp. 97-108, 1994.1

11) Zaino, H., Miyagishi, Y.:Relation of Sequence Landscape of Fundamental space Structure and Sequence Landscape of Visual Behavior, Journal of Architecture, Planning and Environmental Engineering (Transactions of AIJ), No.438, pp.79-85, 1992.8 材野博司，宮岸幸正：基本構造シークエンス景観と行動シークエンス 景観との関係, 日本建築学会計画系論文報告集, No. 438, pp. 79-85, 1992.8

12) Miyagishi,Y., Zaino,H.: A Study of Visual Sequence of Landscapes According to Visual Behavior and Open-Close of Space-, Journal of the City Planning Institute of Japan, No.26, pp. 433-438, 1991.5 宮岸幸正，材野博司，景観のシークエンスに関する基礎的研究，都市 計画論文集, No. 26, pp. 433-438, 1991.5

13) Masuoka,R., Zaino,H.,: A Study on the Sequence of Landscape with Pedestrian Action and Response, Journal of Architecture, Planning and Environmental Engineering (Transactions of AIJ), Vol.62, No.502, pp. 163-169, 1997.12
益岡了，材野博司：シークェンス景観における歩行者の行動と反応の 研究，日本建築学会計画系論文集，Vo1.62， No. 502， pp. 163-169, 1997. 12

14) Mitsuki, M., Uno, H., Munakata, J., Hirate, K., Yasuoka, M.: A Study on the Way-Finding Process Considering the Change in the State of Mind -Sequence of the change in the mental state measured by "degree of anxiety", Journal of Environmental Engineering (Transactions of AIJ), Vol.69, No.583, pp. 49-56, 2004.9 三ツ木美恵子, 宇野宏司, 宗方淳, 平小太郎, 安岡 正人：心理変化に 注目した経路探索プロセスに関する研究：「不安度」を指標とした心 理変化シークエンス, 日本建築学会環境系論文集, Vol.69, No. 583, pp. $49-56,2004.9$ 


\author{
Takuya SUGIYAMA *1 and Yohsuke YOSHIOKA *2 \\ ${ }^{1}$ Architectural Design Dept., Architectural Div., KUME SEKKEI Co. Ltd., M.Eng. \\ ${ }^{2}$ Assoc. Prof., Graduate School of Engineering, Chiba University, Dr. Eng.
}

In this study, we conducted two experiments using immersive virtual environment technology to test the relationship between the shape of the "Leading Passage" and the perceived ceiling height of the "High Ceiling Room". In order to quantify the amount of psychological height of the ceiling, we implemented a method to adjust the height of the ceiling up or down by the subject's own manipulation.

In Experiment 1, subjects were asked to walk through six different shapes of "Leading Passage" - "going straight," "going up," "going down," "going through," "turning left," and "turning right" - to "High Ceiling Room" and asked to adjust the ceiling height of the room. The results were as follows.

- Connection or Un-connection of "Leading Passage" led to a change in the amount of psychological ceiling height perceived in the "High Ceiling Room".

- The shape of "Leading Passage" led to a change in the amount of psychological ceiling height perceived in the "High Ceiling Room".

- The amount of psychological ceiling height perceived in the "High Ceiling Room" is lower after passing through an upward "Leading Passage" than after passing through a flat "Leading Passage".

In Experiment 2, subjects were asked to walk through three different shapes of "Leading Passage" - "going straight," "going up," "going down," - to "High Ceiling Room" and asked to adjust the ceiling height of the room. The results were as follows.

- As in Experiment I, the amount of psychological ceiling height perceived in the "High Ceiling Room" varied depending on the shape of "Leading Passage".

- The amount of psychological ceiling height perceived in the "High Ceiling Room" is lower after passing through an upward "Leading Passage" than after passing through a downward "Leading Passage".

• When walking in an upward "Leading Passage", subjects look more upward in the environment than when walking in a downward "Leading Passage", at the point where the ceiling of the "High Ceiling Room" begins to be visible over the exit of "Leading Passage".

• When walking in a downward "Leading Passage", subjects look more upward in the environment than when walking in an upward "Leading Passage", at the exit of "Leading Passage".

In both experiments, subject tends to perceived the ceiling height of the "High Ceiling Room" higher after they walked through a flat or a downward "Leading Passage" and perceived the ceiling height of the "High Ceiling Room" lower after they walked through an upward "Leading Passage", than in the case without "Leading Passage" .These results indicate that the ceiling height in the "High Ceiling Room" can be controlled by passing through the approach space with a suitable shape. 